\title{
Refugee Health: An Ongoing Commitment and Challenge
}

\author{
Jimmy T. Efird ${ }^{1, *}$ and Pollie Bith-Melander ${ }^{2}$ \\ 1 Centre for Clinical Epidemiology and Biostatistics (CCEB), School of Medicine and Public Health, \\ The University of Newcastle (UoN), Callaghan, NSW 2308, Australia \\ 2 Alternatives in Action, Oakland, CA 94610, USA; polliebith@gmail.com \\ * Correspondence: jimmy.efird@stanfordalumni.org; Tel.: +1-650-248-8282
}

Received: 9 January 2018; Accepted: 10 January 2018; Published: 13 January 2018

\begin{abstract}
Refugees represent a diverse group of displaced individuals with unique health issues and disease risks. The obstacles facing this population have their origins in war, violence, oppression, exploitation, and fear of persecution. Regardless of country of origin, a common bond exists, with refugees often confronting inadequate healthcare resources, xenophobia, discrimination, and a complex web of legal barriers in their new homelands. In many cases, the plight of refugees is multigenerational, manifesting as mental health issues, abuse, poverty, and family disruption. The health trajectory of refugees remains an ongoing commitment and challenge.
\end{abstract}

Keywords: refugee health; exploitation; lack of resources; struggles of cultural transition; hygiene/ sanitation; disease risk; early marriage

\section{Introduction}

While civilization has a long history of major displacement crises, recent times have witnessed alarmingly high levels of families and individuals seeking refuge and protection from hostile world conditions. At latest count, nearly 66 million people have been forcibly displaced from their homes owing to conflict or persecution, with an additional 10 million living in statelessness [1]. This amounts to approximately 20 new refugees every minute, over half of whom are under the age of 18. The healthcare needs of this population are complex. Solutions are frequently mired in political disarray, misguided national security concerns or divergent views regarding the best path forward. The multicultural and multilingual composition of refugees further confounds preparedness efforts and crises management. Increasingly, refugees are encountering extended delays and suboptimal responses in their resettlement to a safe haven, often influenced by populism and partisan ideology rather than evidence-based public health data.

\section{Moving Toward a Solution}

Solving the healthcare requirements of a vulnerable refugee population merits a flexible framework. This is important to facilitate understanding by health system providers and to elicit an optimal response by receiving government agencies. Originating from various regions of the world, the needs of refugees must be carefully considered in the context of cultural and economic differences with their host countries. Diseased burden and risk is best placed in a proper public health context, supported by legitimate scientific facts and realistic healthcare policy approaches, in order to achieve a lasting solution.

The consideration of a wide range of topics is needed to better inform decision makers and the medical community [2-25]. This includes, but is not limited to: Health screening examinations; community-based/multi-lingual health education and resources for refugees; improved awareness 
of refugee health disparities; disease tracking and reporting systems; multidisciplinary response to disease outbreaks; refugee utilization or lack thereof of healthcare resources/insurance; barriers to healthcare; health selection/trajectory of refugees; hematologic genetic disorders; chronic and mental health issues; abuse; discrimination; exploitation; infectious diseases; immunization strategies; environmental exposures related to disease; hygiene and sanitation; healthy lifestyle choices; illegal activities/injuries (assault, rape, battery); and assimilation analysis. Healthcare concerns relating to economic challenges, language barriers, the struggles of a cultural transition, geographic origin, and refugee camp living conditions are other topics that may have a significant impact on refugee resettlement and their healthcare needs.

\section{Conclusions}

The United States, Europe, China, and Israel are some of the major world powers that have played a leading role in providing humanitarian aid to a world in crisis. Recognizing the healthcare needs of refugees is consistent with the belief that all people deserve equitable access to quality medical treatment and prevention. Facilitating the cooperation between countries, encouraging open political dialog, and developing strategies to increase philanthropic involvement from the private/non-governmental sector are key to achieving long-term solutions for the health and safety of displaced individuals throughout the world.

Acknowledgments: We thank the contributors to this Special Issue on Refugee Health and Paul B. Tchounwou for his support and encouragement.

Author Contributions: Jimmy T. Efird and Pollie Bith-Melander contributed equally to the writing of this Editorial.

Conflicts of Interest: The authors declare no conflict of interest.

\section{References}

1. UNHCR: The UN Refugee Agency. Figures at a Glance. Available online: http:/ / www.unhcr.org/figures-ata-glance.html (accessed on 8 January 2018).

2. Blitz, B.K.; d'Angelo, A.; Kofman, E.; Montagna, N. Health Challenges in Refugee Reception: Dateline Europe 2016. Int. J. Environ. Res. Public Health 2017, 14, 1484. [CrossRef] [PubMed]

3. Sigvardsdotter, E.; Nilsson, H.; Malm, A.; Tinghog, P.; Gottvall, M.; Vaez, M.; Saboonchi, F. Development and Preliminary Validation of Refugee Trauma History Checklist (RTHC)—A Brief Checklist for Survey Studies. Int. J. Environ. Res. Public Health 2017, 14, 1175. [CrossRef] [PubMed]

4. Bith-Melander, P.; Chowdhury, N.; Jindal, C.; Efird, J.T. Trauma Affecting Asian-Pacific Islanders in the San Francisco Bay Area. Int. J. Environ. Res. Public Health 2017, 14, 1053. [CrossRef] [PubMed]

5. Park, S.; Lee, M.; Jeon, J.Y. Factors Affecting Depressive Symptoms among North Korean Adolescent Refugees Residing in South Korea. Int. J. Environ. Res. Public Health 2017, 14, 912. [CrossRef] [PubMed]

6. Bozorgmehr, K.; Goosen, S.; Mohsenpour, A.; Kuehne, A.; Razum, O.; Kunst, A.E. How Do Countries' Health Information Systems Perform in Assessing Asylum Seekers' Health Situation? Developing a Health Information Assessment Tool on Asylum Seekers (HIATUS) and Piloting It in Two European Countries. Int. J. Environ. Res. Public Health 2017, 14, 894. [CrossRef] [PubMed]

7. Cherri, Z.; Gil Cuesta, J.; Rodriguez-Llanes, J.M.; Guha-Sapir, D. Early Marriage and Barriers to Contraception among Syrian Refugee Women in Lebanon: A Qualitative Study. Int. J. Environ. Res. Public Health 2017, 14, 836. [CrossRef] [PubMed]

8. Sykes, L.; Bhayat, A.; Bernitz, H. The Effects of the Refugee Crisis on Age Estimation Analysis over the Past 10 Years: A 16-Country Survey. Int. J. Environ. Res. Public Health 2017, 14, 630. [CrossRef] [PubMed]

9. Georgiadou, E.; Morawa, E.; Erim, Y. High Manifestations of Mental Distress in Arabic Asylum Seekers Accommodated in Collective Centers for Refugees in Germany. Int. J. Environ. Res. Public Health 2017, 14, 612. [CrossRef] [PubMed]

10. Giambi, C.; Del Manso, M.; Dente, M.G.; Napoli, C.; Montano-Remacha, C.; Riccardo, F.; Declich, S. Immunization Strategies Targeting Newly Arrived Migrants in Non-EU Countries of the Mediterranean Basin and Black Sea. Int. J. Environ. Res. Public Health 2017, 14, 459. [CrossRef] [PubMed] 
11. Ganczak, M.; Czubinska, G.; Korzen, M.; Szych, Z. A Cross-Sectional Study on Selected Correlates of High risk Sexual Behavior in Polish Migrants Resident in the United Kingdom. Int. J. Environ. Res. Public Health 2017, 14, 422. [CrossRef] [PubMed]

12. Wang, Q. Health of the Elderly Migration Population in China: Benefit from Individual and Local Socioeconomic Status? Int. J. Environ. Res. Public Health 2017, 14, 370. [CrossRef] [PubMed]

13. Bostean, G.; Ro, A.; Fleischer, N.L. Smoking Trends among U.S. Latinos, 1998-2013: The Impact of Immigrant Arrival Cohort. Int. J. Environ. Res. Public Health 2017, 14, 255. [CrossRef] [PubMed]

14. Alemi, Q.; Stempel, C.; Koga, P.M.; Smith, V.; Danis, D.; Baek, K.; Montgomery, S. Determinants of Health Care Services Utilization among First Generation Afghan Migrants in Istanbul. Int. J. Environ. Res. Public Health 2017, 14, 201. [CrossRef] [PubMed]

15. Pottie, K.; Hui, C.; Rahman, P.; Ingleby, D.; Akl, E.A.; Russell, G.; Ling, L.; Wickramage, K.; Mosca, D.; Brindis, C.D. Building Responsive Health Systems to Help Communities Affected by Migration: An International Delphi Consensus. Int. J. Environ. Res. Public Health 2017, 14, 144. [CrossRef] [PubMed]

16. Gabriel, P.; Kaczorowski, J.; Berry, N. Recruitment of Refugees for Health Research: A Qualitative Study to Add Refugees' Perspectives. Int. J. Environ. Res. Public Health 2017, 14, 125. [CrossRef] [PubMed]

17. Nidzvetska, S.; Rodriguez-Llanes, J.M.; Aujoulat, I.; Gil Cuesta, J.; Tappis, H.; van Loenhout, J.A.; Guha-Sapir, D. Maternal and Child Health of Internally Displaced Persons in Ukraine: A Qualitative Study. Int. J. Environ. Res. Public Health 2017, 14, 54. [CrossRef] [PubMed]

18. Stempel, C.; Sami, N.; Koga, P.M.; Alemi, Q.; Smith, V.; Shirazi, A. Gendered Sources of Distress and Resilience among Afghan Refugees in Northern California: A Cross-Sectional Study. Int. J. Environ. Res. Public Health 2016, 14, 25. [CrossRef] [PubMed]

19. Chau, K.; Kabuth, B.; Chau, N. Association between Suicide Ideation and Attempts and Being an Immigrant among Adolescents, and the Role of Socioeconomic Factors and School, Behavior, and Health-Related Difficulties. Int. J. Environ. Res. Public Health 2016, 13, 70. [CrossRef] [PubMed]

20. Neerup Handlos, L.; Fog Olwig, K.; Bygbjerg, I.C.; Norredam, M. Return Migrants' Experience of Access to Care in Corrupt Healthcare Systems: The Bosnian Example. Int. J. Environ. Res. Public Health 2016, $13,924$. [CrossRef] [PubMed]

21. Toikkanen, S.E.; Baillot, A.; Dreesman, J.; Mertens, E. Seroprevalence of Antibodies against Measles, Rubella and Varicella among Asylum Seekers Arriving in Lower Saxony, Germany, November 2014-October 2015. Int. J. Environ. Res. Public Health 2016, 13, 650. [CrossRef] [PubMed]

22. Hong, M.K.; Varghese, R.E.; Jindal, C.; Efird, J.T. Refugee Policy Implications of U.S. Immigration Medical Screenings: A New Era of Inadmissibility on Health-Related Grounds. Int. J. Environ. Res. Public Health 2017, 14, 7. [CrossRef] [PubMed]

23. Milton, A.H.; Rahman, M.; Hussain, S.; Jindal, C.; Choudhury, S.; Akter, S.; Ferdousi, S.; Mouly, T.A.; Hall, J.; Efird, J.T. Trapped in Statelessness: Rohingya Refugees in Bangladesh. Int. J. Environ. Res. Public Health 2017, 14, 942. [CrossRef] [PubMed]

24. Giorgi Rossi, P.; Riccardo, F.; Pezzarossi, A.; Ballotari, P.; Dente, M.G.; Napoli, C.; Chiarenza, A.; Velasco Munoz, C.; Noori, T.; Declich, S. Factors Influencing the Accuracy of Infectious Disease Reporting in Migrants: A Scoping Review. Int. J. Environ. Res. Public Health 2017, 14, 720. [CrossRef] [PubMed]

25. Flynn, M.A.; Wickramage, K. Leveraging the Domain of Work to Improve Migrant Health. Int. J. Environ. Res. Public Health 2017, 14, 1248. [CrossRef] [PubMed]

(C) 2018 by the authors. Licensee MDPI, Basel, Switzerland. This article is an open access article distributed under the terms and conditions of the Creative Commons Attribution (CC BY) license (http:/ / creativecommons.org/licenses/by/4.0/). 